\title{
Monitoring, Restoration, and Source Water Protection: Canadian Community-Based Environmental Organizations' Efforts towards Improving Aquatic Ecosystem Health
}

\author{
Chris Garda ${ }^{1}$, Heather Castleden ${ }^{2, *}$ and Cathy Conrad ${ }^{3}$ \\ 1 School for Resource and Environmental Studies, Dalhousie University, 1459 Oxford St, Halifax, NS B3H 4R2, \\ Canada; cgard515@gmail.com \\ 2 Department of Geography and Planning \& Department of Public Health Sciences, Queen's University, \\ 68 University Ave, Kingston, ON K7L 3N9, Canada \\ 3 Department of Geography and Environmental Studies, St. Mary's University, 923 Robie St., Halifax, \\ NS B3H 3C3, Canada; cconrad@smu.ca \\ * Correspondence: heather.castleden@queensu.ca; Tel.: +1-613-533-6000 (ext. 77216)
}

Academic Editor: Robert Patrick

Received: 7 December 2016; Accepted: 4 March 2017; Published: 13 March 2017

\begin{abstract}
In Canada, environmental monitoring has been the responsibility of government for decades; however, funding cutbacks have left many agencies unable to provide comprehensive coverage. This has stimulated a rise in community-based water monitoring (CBWM) organizations. These organizations, operating at multiple scales, have tasked themselves with monitoring aquatic ecosystems. Additionally, they often engage in restoration projects stemming from their monitoring work. Despite the growing abundance of CBWM organizations, there is uncertainty as to whether their activities lead to aquatic ecosystem benefits. A thematic analysis of photographic and qualitative interview data was employed to examine restoration projects conducted by five CBWM organizations, and the projects' potential impact on source waters. Findings show that while they are conducting activities that show physical change, which is indicative of ecosystem improvement, examples of measurable responses within aquatic ecosystems remain rare. Monitoring, restoration, and source water protection processes are challenged by a lack of funding, capacity, and monitoring procedures. Funding, particularly, restricted the extent to which monitoring could be conducted and influenced project scope and scale. This leads to a lack of capacity to conduct large-scale restoration and rigorous scientific monitoring. Consequently, our findings highlight the issues with detecting effects of small-scale projects at the watershed scale.
\end{abstract}

Keywords: community-based water monitoring; restoration; environmental assessment; aquatic ecosystems; source water protection; Canada; photo elicitation

\section{Introduction}

Freshwater environments, the sources of our drinking water, are some of the most threatened ecosystems in the world [1-4]. Ground and surface waters are exposed to increasing and unprecedented threats from anthropogenic stressors that degrade water quality, reduce water availability when it is needed the most (i.e., drought), increase water abundance when it is needed the least (i.e., flooding), destroy habitat, and harm the aquatic life [3,5-9]. Although the causes of these threats are often known, this knowledge has done little to mitigate or eliminate them and it is commonly accepted that the human use of ecosystem goods and services will come at a cost to biodiversity and source water quality $[3,10]$. If the degradation of freshwater sources continues at the current rate, the chance to 
conserve these systems may vanish along with many of the species that depend upon them $[3,10]$. In order to protect drinking water (and water for other purposes) there must be an understanding of the complex interactions between human activities and aquatic ecosystem health [11]. Source water protection vis-à-vis water monitoring and other interconnected activities provides a way to understand these interactions and assess the state of aquatic ecosystems to determine if they are vulnerable to harm [12].

In Canada, monitoring for ecosystem health and source water protection has historically been the responsibility of municipal, provincial/territorial, and federal governments. However, declines in funding have left many departments wanting in terms of consistent and comprehensive monitoring, resulting in the fragmentation of monitoring data [13-16]. This fragmentation inhibits governments' abilities to collect the data necessary for making informed decisions regarding water quality and aquatic ecosystem health [15,17]. As government-run water monitoring programs have declined, community-based water monitoring (CBWM) organizations have become more prevalent throughout Canada [17]. These organizations have 'adopted' streams, rivers, lakes, and watersheds and tasked themselves with conducting water monitoring, public education, source water protection, mitigation, and restoration work within them. The purpose of this paper is two-fold: (1) to examine whether restoration activities conducted by CBWM organizations lead to observable or measurable benefits within aquatic ecosystems for overall source water protection, and (2) to identify challenges faced by CBWM organizations in meeting restoration objectives.

\subsection{Community-Based Water Monitoring in Canada}

CBWM is "a process where concerned citizens, government agencies, industry, academia, community groups, and local institutions collaborate to monitor, track, and respond to issues of common community concern" [18] (p. 410). CBWM organizations actively participate in 'citizen science', a process where a non-professional scientist takes on the role of a volunteer scientist in conducting scientific research $[19,20]$, and 'community science', the interaction of community, agency, and industry, in generating new scientific knowledge [21]. These organizations often exist in watersheds where human activities have impacted or have the potential to negatively impact the aquatic environment. CBWM organizations conduct monitoring throughout these watersheds and in many, if not most, circumstances, use the information collected to guide source water protection, restoration, mitigation, and enhancement projects.

CBWM often faces challenges regarding credibility, capacity, and funding $[15,16,18]$. The validity and methods of data collected by citizen scientists is often questioned by the academic community, professionally-trained scientists, and government agencies [22,23]. This can partially be credited to a lack of stringent sampling protocols and training, and fragmentation in monitoring data often caused by a lack of funding $[12,15]$. While there is skepticism on the accuracy of volunteer-collected data concerning water quality, studies have indicated that volunteer-collected data can be comparable to that of expert-collected data [23-27]; these studies encompass biological, physical, and chemical water monitoring parameters.

Despite the abundance of CBWM organizations, there remains a gap in academic literature regarding the benefit, if any, that the existence of CBWM provides to aquatic ecosystems [28]. Although subjective evidence regarding the environmental benefits of CBWM and citizen science exists within grey literature, more peer-reviewed literature must be published to validate these claims [28]. To begin to address this gap, Conrad and Hilchey (2011) [28] identified a need to compare and contrast cases where citizen science and CBWM have influenced benefits to the watersheds being monitored for ecosystem health and source water protection. As noted above, our paper responds to their call to identify potential observable and measurable benefits through CBWM and, moreover, unveils some of the challenges CBWM organizations face in their work towards source water protection. Before providing our case context, we provide a brief review of the relevant literature about source water monitoring, aquatic ecosystems, and restoration. 


\subsection{Water Monitoring and Restoration}

The quality of a water source is determined by evaluating its physical, chemical, and biological traits [29]. Each evaluation method has its strengths and weaknesses, and plays a role in identifying the current state of aquatic environments. These traits can also be used to track the success of restoration efforts within the system, although implementing the monitoring procedures to do so can be challenging. While there has been an ever-increasing interest in conducting restoration projects, there has been little in the way of major advances in our knowledge of how to successfully implement restoration [30-34]. Despite the abundance of restoration projects and the immense amount of time, money, and resources invested into them, few projects incorporate the monitoring necessary to determine if the project was successful or not $[11,34,35]$. Very little documentation or data have been developed to highlight the steps required to implement restoration in freshwater aquatic ecosystems successfully $[7,35,36]$, and even among the projects that are evaluated, many of them lack the procedural implementations that allow for thorough scientific analysis [7,37]. There are multiple factors that contribute to this, but some of the major ones are: lack of understanding, agreement, funding, and scale of restoration being conducted. Some grey literature documents have been developed within Canada to aid in restoration and best management practices [38,39], but these sources are for restoration in general and not specific to aquatic ecosystems.

Aquatic ecosystems are complex, containing numerous physical, chemical, and biological relationships that influence biodiversity, water quality, and habitat that are not fully understood [40-43]. These relationships are further complicated by each system being unique; therefore, successful restoration in one aquatic ecosystem does not necessarily mean that the technique used would be transferable to another [44]. Within the scientific community there is a general consensus that restoration is important, but there are multiple views on what successful restoration constitutes, the process required to achieve this goal, or the monitoring procedures required to properly track and document ecosystem changes at a project level $[34,45]$. When planning and conducting restoration, the current funding structure favors action-oriented projects, meaning that funds are often allocated to conduct the physical project work but cannot be used to support pre- and post-project monitoring, including efforts geared towards source water protection [40,43]. Moreover, large-scale restoration has been identified as having a higher chance of success, as changes in the aquatic ecosystem will be more significant and easier to monitor and track $[46,47]$. Unfortunately, large-scale projects are not often economically or socially feasible due to limited resources and conflicts of interest [46,47]; in these instances, small-scale restoration can be effective at targeting specific problems, but changes at this scale can be difficult to monitor and track [47].

Both citizen and professional scientists agree that monitoring of restoration projects is a key component in determining project success [48-51], but there are also other key factors to consider. For example, Kondolf (1995) [40] and Geist (2015) [52] both identify five components for effective stream restoration: (1) clear objectives, and specific identification of restoration objectives; (2) baseline data assessment of the current status of the ecosystem; (3) study design that sets priorities in order to achieve the restoration objective; (4) commitment to the long term that allows for sufficient post-restoration monitoring; and (5) willingness to acknowledge and report on failure. Additionally, Geist (2015) [52] proposes the identification of bottlenecks that would hinder restoration action. Lake (2001) [33] highlights the need for restoration projects to have participation from resource management agencies, adequate design with a clear goal that utilizes pre-restoration data, proper monitoring (physical, chemical, and biological), transparent reporting of the project outcome, and consideration as to the time required for natural processes and biota to recover. Palmer et al. (2005) [34] suggest that success should take into account three different aspects: stakeholder values, project learning outcomes, and ecological success. Palmer et al. (2005) [34] further divides ecological success into five categories: (1) a clear guiding image of the aquatic system in a state that is achievable by restoration; (2) the targeted physical and chemical components of the system are measurable and enhanced; (3) restoration leaves the aquatic system in a state where it can become self-sustaining without continual maintenance; 
(4) restoration projects leave no lasting harm within the system; and (5) information regarding the conditions of the project site is collected both before and after the project and made publicly available.

Another important aspect of restoration is strategically targeting known impacts that affect aquatic ecosystem biodiversity, habitat, and water quality; the mitigation of these impacts will prevent further degradation to the ecosystem and allow for natural restoration to take place [53-57]. Beechie et al. (2008) [56] propose a hierarchical approach to restoration based on the probability of success, response time within the aquatic ecosystem, and longevity of the restoration method implemented. First, this approach should focus on the protection of source waters that serve as high-quality habitats, as this provides the greatest benefit to the aquatic ecosystem $[45,52,56]$; second, restoration actions should target the reconnection of fragmented habitat [56,58]; and third, processes that maintain and create habitat should be restored (e.g., flow regime, water quality, riparian habitat) $[45,56,59,60]$. Where applicable, these strategies should be paired with the removal or reduction of current impacts within the aquatic ecosystem, using undisturbed reference sites as templates [57].

Within the literature there are some prominent criteria for restoration success: clear project goals and objectives [33,34,40,52,54,61]; the collection of baseline data and pre-restoration conditions $[33,34,37,40,52,62]$ and clear reporting or documentation of the outcome including failure $[11,33,34,51,52]$. Restoration activities should be strategically targeted to prioritize the preservation of high-quality habitat, reconnection of habitat, and restoring processes that maintain and create habitat $[45,53,56,58]$. The recent review by Geist and Hawkins (2016) [57] on habitat recovery and restoration as well as Mueller and Geist (2016) [63] and Mueller et al. (2013) [64] in terms of which monitoring efforts are necessary are useful additional sources to turn to; but the core message we want to convey here is that determining restoration success often does not necessarily require a deep taxonomic resolution for most stakeholders. Rather, consideration of a diversity of indicators may be an appropriate approach depending on CBWM (or governmental) capacity and resources. We turn now to our study context to explore these ideas further.

\subsection{Case Context}

This research project was nested within a larger Community-University Research Alliance (CURA) program of research called 'CURA H20', a 5-year Social Sciences and Humanities Research Council of Canada (SSHRC) funded project for community-based integrated water monitoring and management in Atlantic Canada and abroad. The CURA H20 Research Alliance provided a collaborative network where citizen groups and academics worked together to develop standardized data collection methods, and provided academic guidance to CBWM organizations and vice versa. At the time of data collection all five organizations that participated in the study reported here were partners in CURA H2O.

\section{Materials and Methods}

\subsection{Recruitment, Data Collection, and Data Analysis}

Of the 20+ CBWM organizations affiliated with the CURA H20 Research Alliance, five were recruited to participate in our study, based on the capacity of the project and existing sample pool. These organizations were selected using a purposeful sampling method [65], seeking the participation of key informants from each organization. Key informants are defined as persons who have in-depth knowledge about past and present activities of their CBWM organization, and are actively involved in planning and organization [66].

We identified five inclusion criteria for CBWM organizations to participate in our study. These criteria were: (1) participation in the CURA H2O Research Alliance; (2) monitoring for a minimum of 6 years to ensure the potential for observable outcomes of any monitoring or restoration activities [67]; (3) retention of members who were knowledgeable of historical and current activities of the CBWM organization; (4) maintenance of supplementary records of activities conducted (e.g., photographs, 
project reports, and journal logs); and (5) continuous monitoring throughout this timeframe and retention of data records.

We identified five inclusion criteria for selecting key informants for qualitative semi-structured interviews. These criteria were: (1) they were self-identified, group-identified, or identified by the CURA H2O research team; (2) they were voluntary and willing participants [68]; (3) they were involved in the planning, organization, and implementation of CBWM activities [66,69]; (4) they had in-depth knowledge of the past and present activities conducted by their CBWM organization, and could explain the process from start (planning) to finish (follow-up); (5) and they were a primary source of information, someone who was directly involved with the information being provided [69]. A total of eight participants were recruited from the five CBWM organizations (see Table 1).

Table 1. Key Informant Guide.

\begin{tabular}{|c|c|c|c|}
\hline Participant Code & Organization & Province & Organization Established (Years) \\
\hline P-01 & \multirow{2}{*}{ CBWM \#1 } & \multirow{2}{*}{ Nova Scotia } & \multirow{2}{*}{$\sim 27$} \\
\hline $\mathrm{P}-02$ & & & \\
\hline P-03 & CBWM \#2 & New Brunswick & $\sim 21$ \\
\hline P-04 & \multirow{2}{*}{ CBWM \#3 } & \multirow{2}{*}{ Nova Scotia } & \multirow{2}{*}{$\sim 11$} \\
\hline $\mathrm{P}-05$ & & & \\
\hline P-06 & \multirow{2}{*}{ CBWM \#4 } & \multirow{2}{*}{ Prince Edward Island } & \multirow{2}{*}{$\sim 21$} \\
\hline $\mathrm{P}-07$ & & & \\
\hline P-08 & CBWM \#5 & Nova Scotia & $\sim 25$ \\
\hline
\end{tabular}

\subsection{Data Collection and Analysis}

A two-phased interview structure was used for data collection consisting of Phase 1-semi-structured interviews, and Phase 2-photo-elicitation interviews. Phase 1 interviews were used to gain general knowledge about the CBWM organizations and to verify key informant participation. The end goal of the Phase 1 interview was to identify subject matter suitable to use in the second phase of the research study: activities conducted by the CBWM organization that have the ability to benefit source waters and the natural ecosystem and have photographic documentation. A code list was used to identify a priori codes generated in consultation with the CURA H2O research group and during the literature review [70,71]. These codes were imputed into the data using deductive analysis during the first reading of the interview transcript [72]. A second round of coding was conducted using inductive analysis to identify and categorize newly emergent themes that were not identified in the deductive analysis [73]. A code list was updated and maintained throughout this process that defined and kept track of all of the codes used in the analysis [73]. After coding was completed, parent codes, codes that focus on broad categories, were identified and classified as parent codes [70]. The remaining themes were classified as child codes that were paired with their corresponding parent code. For example, child codes of 'riparian zone restoration' and 'in-stream restoration' would be categorized under the parent code of 'restoration'.

Phase 2 photo-elicitation interviews focused in-depth on three to five activities that were identified during the Phase 1 interview. Participants were asked to supply photographs that depicted the activity areas pre-, during, and post-activity. These were printed and displayed during the interview. Photo elicitation interviews, in which photographs are used to facilitate the conversation [74], were employed to discuss the planning for, implementation of, and follow-up to each activity. Interviews were composed of a general line of questioning asking participants to identify the activity being conducted, the reason it was being conducted, the planning process, how it was conducted, project follow-up required, and whether (to what extent) any benefits to the ecosystems were identified. This process was repeated for each set of pictures. Where available, accompanying monitoring data and project 
reporting was requested for the activities discussed. Analysis of Phase 2 interviews followed the same coding structure as described for Phase 1 interview analysis. New parent and child codes were identified during this analysis and were subsequently defined, classified, and incorporated into the analysis.

Phase 1 and 2 interviews were transcribed verbatim and coded using NVivo10 ${ }^{\mathrm{TM}}$, a qualitative data analysis software program. All data were scrutinized using a thematic analysis [75] to identify process, methods, and practitioners involved in each project type. In total, 23 projects were discussed during the Phase 2 interviews, with 15 projects matching the research criteria of having the ability to impact or enhance the aquatic environment. These projects were the focus of the analysis. The remaining eight projects were outliers: projects such as public education, staff training, school programs, projects still in the planning stage, and baseline monitoring programs. Although these projects are relevant, their impact on the ecosystem had no unit of measure or visual indicators to determine how they affect the aquatic ecosystem.

\section{Results}

Our analysis of the data revealed six key themes that relate to our overarching research purpose about whether restoration activities conducted by CBWM organizations lead to observable or measurable benefits within aquatic ecosystems for overall source water protection. However, what clearly surfaced from the data, as is often the case with qualitative inquiry going in new and unexpected directions, was a central focus on the challenges that CBWM organizations are facing in terms of meeting their restoration objectives. These themes are: (1) a majority of the restoration and water protection projects required regulatory approval; (2) projects were planned and implemented with clear goals and objectives; (3) funding sources and land availability often restricted the size and scope of projects, and the extent to which monitoring was conducted; (4) monitoring at a watershed scale was inadequate to detect environmental changes at a project specific level; (5) post-project reporting was completed for all projects that required regulatory approval, and reports were made publicly available for seven of the 15 projects; and (6) a majority of projects were targeted at reconnecting habitat and restoring processes that would protect drinking water sources and maintain aquatic habitat.

The following sections are structured to, first, discuss the general aspects of the restoration process, and second, focus more specifically on the individual project categories identified in Table 2 . The findings also include three project cases that are used to demonstrate specific restoration projects in depth: Case 1-Dam Removal; Case 2-Sediment Control; and Case 3-Riparian Zone Restoration.

Table 2. Summary of Restoration Projects.

\begin{tabular}{|c|c|c|c|c|}
\hline Project Type & $\begin{array}{c}\text { Number of } \\
\text { Projects Assessed }\end{array}$ & Anthropogenic * & $\begin{array}{c}\text { Naturally } \\
\text { Occurring ** }\end{array}$ & $\begin{array}{c}\text { Regulatory Approval } \\
\text { Required (\# of Projects) }\end{array}$ \\
\hline $\begin{array}{l}\text { Habitat connectivity } \\
\text { and fragmentation }\end{array}$ & 6 & 5 & 1 & 6 \\
\hline $\begin{array}{l}\text { Sediment control and } \\
\text { riparian zone enhancement }\end{array}$ & 4 & 4 & 0 & 4 \\
\hline In stream enhancement & 2 & 2 & 0 & 1 \\
\hline Out of stream enhancement & 3 & 3 & 0 & 0 \\
\hline
\end{tabular}

\subsection{Project Approval Process}

Each of the CBWM organizations operated under a 'blanket permit' or 'blanket approval' issued by Canada's federal Department of Fisheries and Oceans or one of the provincial regulatory agencies, allowing them to conduct small-scale watercourse alterations. These permits granted permission for CBWM organizations to conduct in-stream and terrestrial work within a defined geographic location. 
Work conducted under the permit had to be approved by regulatory agencies before it could be conducted. Projects that were considered low risk to cause harm to aquatic environments, such as garbage removal or tree planting outside of the riparian zone, were exempted from approval under the permit.

"What we have to do is submit notification just in case they [the regulatory agency] have any concerns a couple weeks in advance of doing the work. So we submit the geographic location, the description of the work that we're going to do, [and] the dates that we intend to do the work ..." $"(\mathrm{P}-08)$

If the regulatory agency had any questions or concerns regarding the project, they were addressed before projects were approved. Additionally, regulatory agencies may request the preparation of detailed project plans that highlight the goal of the project, the procedural implementation, and documentation that supported the methodology of the technique being used. Permits stipulated the timeframe in which projects could be conducted and for any work that falls outside this timeframe the permit required an amendment.

"So we have a permit ... you can't get into the streams until the first of June and that takes us all the way until the first of December that we can do in-stream work." (P-07)

"After that we would have to get, basically, an amendment to our blanket permit if we were to extend it to going in after December. Additionally, if we have a major obstruction, like a beaver dam, we would have to get additional permission from the province to go and remove that depending on the scale." (P-06)

Moreover, landowner approval was required to conduct projects on privately owned land; however, landowner approval did not absolve CBWM organizations from obtaining regulatory approval.

\subsection{Project Planning, Conducting, and Follow-Up}

Project planning was primarily conducted within CBWM organizations with professional, academic, and regulatory consultation when required. Project planning was influenced by funding sources, group capacity, procedural documentation, access and availability to project locations, monitoring data, and expertise. Outside expertise was often utilized when implementing new restoration strategies or when organizations lacked the capacity or equipment to conduct a project. Organizations also sought training for restoration techniques where they lacked experience and expertise. Ten of the 15 projects utilized expert consultation in the project planning process.

"Well the planning of this was to develop a training session with the Guardians so they have some awareness, knowledge, of digger logs; what they are used for, how they're implemented, how to put them in. So this is an exercise to get them [the guardians] awareness of that, to actually apply it in real situations." (P-05)

In 12 of 15 projects, the project location was identified during watershed surveys where specific areas were targeted and assessed visually by CBWM staff. Visual assessment was an important tool in identifying project locations, and as a trigger for more in-depth assessment to be conducted. Specifically, visual assessment was a key component in identifying and assessing sedimentation sites, riparian zone conditions, and barriers to connectivity. In 3 of 15 projects, water-monitoring data were used to identify specific areas of concern within the watershed. Changes in monitoring parameters between established upstream and downstream monitoring locations were detected in these cases.

All 15 projects identified clear goals and objectives, although on a majority of projects such small-scale change was difficult to verify through water quality monitoring or biotic indicators. This was commonly addressed by CBWM organizations when discussing the impact of small-scale projects at a watershed scale. On a majority of projects CBWM organizations stated that the 
project outcome was observable through visual monitoring, but that water-monitoring results were inconclusive. Although each of the CBWM organizations was actively conducting continual water quality monitoring within their watersheds, monitoring at this scale did not detect change that could be directly related to restoration. Project specific monitoring was conducted on 4 of 15 projects, in these cases physical, chemical, or biological change was detected.

In 12 of the 15 projects, the project was dependent on outside funding and in-kind contributions. Funding sources often restricted the scope of the project, determined the project type, influenced the size of project, and the extent that monitoring could be conducted.

"A lot of the funding we get for this type of project specifies that it's for action; it's for environmental action, environmental improvement, but there is nothing provided to measure that improvement. So we very seldom have that opportunity, the funds, the capacity, to do before and after [monitoring] to actually evaluate the impacts of our projects." $(\mathrm{P}-08)$

On projects where funding was for action only, any monitoring or post-project source water protection (i.e., assessment and maintenance) conducted came at a cost to the CBWM organization. With limited budgets, CBWM organizations indicated that these projects often lacked the data necessary to track environmental changes.

During project implementation CBWM organizations took a lead role in project coordination and supervision in all 15 projects. This role was shared on 5 of 15 projects where contractors were hired to aid in planning and conducting the project. Personnel from regulatory agencies visited project worksites on 6 of the 15 projects to assess project work and ensure compliance. CBWM organizations indicated that regulatory agencies did not have the capacity or personnel to visit all project locations. On a majority of projects, regulatory agencies relied on project reporting to inform them about the project; CBWM organizations stated that for this reason photographic documentation of projects was important in order to give visual reference to project activities.

"They [the regulatory agencies] probably never come out to the site, I think they relied on the pictures that I sent them. But one of them, one individual from those two groups, may have come out to the site to look at it, but I think for the most part, given the site and given our experience, they trust us to do it." (P-02)

“The science, what we're observing and marking in our notes, you can physically see the changes that are happening in the streams, and we think that site photos are an integral part of any project so that you can track your success or failure, essentially." (P-06)

Upon completion, all 15 projects had periodic site visits conducted where CBWM staff visually assessed site conditions and took photographs. In four projects, project specific water monitoring data were collected. Post-project reporting was conducted on 13 projects, with reports made publicly available for seven of these projects.

The following sections provide a synopsis of each of the 15 projects, organized by the four project types (i.e., Habitat Connectivity and Fragmentation; Sediment Control and Riparian Zone Restoration; In Stream Enhancement; and Out of Stream Enhancement). These contain three case studies (i.e., Case 1-Dam Removal; Case 2-Sediment Control; Case 3-Riparian Zone Restoration) that detail specific projects. These sections identify the factors that influenced and shaped each of the projects, and how restoration influenced environmental change.

\subsection{Habitat Connectivity and Fragmentation}

The highest concentration of projects (6), focused on habitat connectivity and fragmentation. These projects implemented the objective of removing or enhancing identified barriers within stream networks to allow for fish passage and thus alleviate habitat fragmentation. All barriers were identified 
through visual monitoring and assessment, and three were verified through standardized monitoring protocols. Five of the six barriers were anthropogenic in nature (four culverts and one dam, see Case 1-Dam Removal), and one was naturally occurring.

For two of the culvert restoration projects a protocol for assessing culverts was adopted from Nova Scotia provincial guidelines (to determine non-barrier culverts), from British Columbia Ministry of Environment [76], Terra Nova National Park [77], the U.S. Department of Agriculture, Forest Service, National Technology and Development Program [78], and Fisheries and Oceans Canada [79]. Sub-watersheds within the larger watershed were strategically targeted based on water chemistry and potential salmonid habitat. Culverts within the targeted areas were assessed based on water quality, culvert type (i.e., shape, material, entry type), embeddedness, length, and slope. Restoration was conducted on culverts assessed as barriers to fish passage, consisting of debris removal, flow regulation, and ensuring that fish could enter and exit the structure. Culverts were then reassessed to ensure that fish passage had been restored. This methodology is being standardized within the province of Nova Scotia, for assessing culverts that cannot be removed from streams.

On the remaining two culvert projects, visual assessment, and in one case a concern for human safety, triggered the projects. In these cases the projects involved the removal of culverts from the outflow of a lake, and from within a feeder brook that connected to the main stream channel (see Figure 1). The structures had originally been installed by a logging company to provide road access across the river, and by a developer for road access to a development that no longer exists. Both roadways had been abandoned and deteriorated to a state where stream crossing was no longer possible, however they still represented a barrier to fish.

"In this case, we knew that there was pretty much a complete blockage to fish passage. And of course that depends on flows as well, but there was a blockage of fish passage. And that was the only issue, and that was so apparent that there wasn't really much need to do flow data or anything like that, so there really wasn't much in the way of monitoring in advance to the project." (P-02)

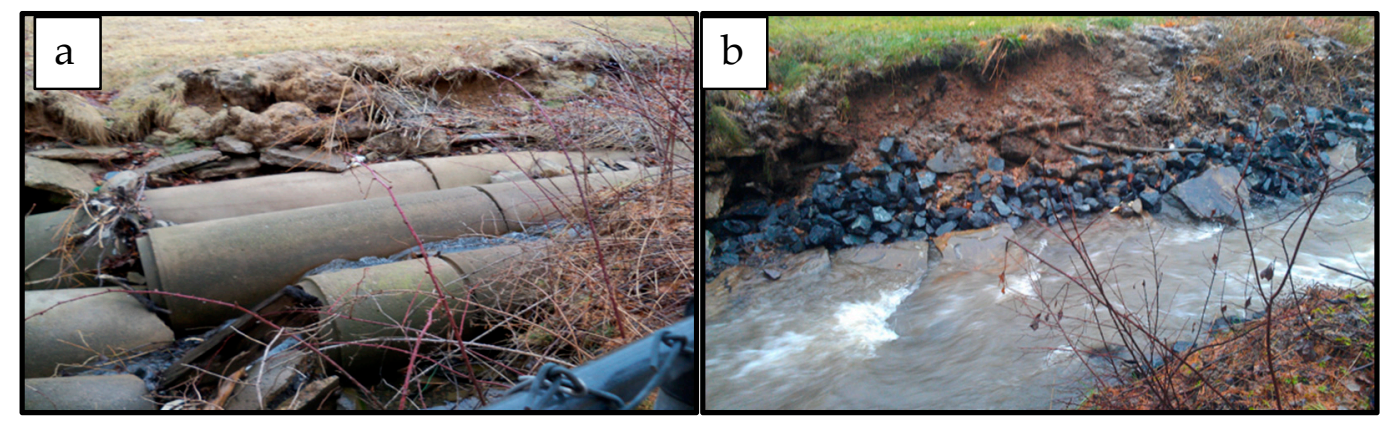

Figure 1. Cement culverts in a feeder brook that were visually assessed as a complete blockage to fish passage (a) pre-removal; and (b) post-removal.

Before the removal of the structures, the project locations were visited with federal and provincial officials who verified the work plan, and approved the project. Project work was conducted within a day for each project, where culverts were removed, banks stabilized, and waste disposed of. Pictures were taken throughout this time, as regulatory agencies were unable to come to the project locations as work was being conducted. Each site was periodically assessed after project completion to ensure that site conditions were being reestablished. Although monitoring data were not collected for these projects, the CBWM organization indicated that the resulting benefit to the ecosystem was readily observable, as natural flow regime and connectivity was restored.

The mitigation of a naturally occurring barrier, a waterfall, utilized the construction of a fishway. The waterfall was a known barrier to fish passage at low water conditions, and poaching at this location 
was frequent. The project was first proposed, planned, and designed by a federal agency. The agency then approached the local CBWM organization with their plan and asked if the organization could provide a portion of the funding for the project, oversee construction, maintain the structure, and conduct annual fish surveys. The CBWM organization was successful in obtaining grant funding from the provincial government and hired a workforce to build the structure. The fishway was successful in allowing fish passage through the waterfall during low water conditions and poaching has decreased significantly. The fishway acts as a salmon monitoring station, and has been utilized for multiple university research studies.

"Also, there's unexpected side benefits. There have been several surveys carried out at the fishway on gaspereau, on eels. People actually see that [the fishway] as a place to do scientific work .... We have now become a focal point in some cases for some types of research. And because we go there every day, counting the salmon and other species, it's also good for us to do water quality monitoring." (P-01)

The CBWM organization reports to the federal agency monthly on the numbers of fish passing through the structure during operation.

\section{Case 1-Dam Removal}

Originally built to create a drinking water reservoir, the dam passed through multiple ownerships before being abandoned (see Figure 2). Existing on a salmon spawning river, concern for the dam's structural integrity and salmon poaching taking place at the obstruction was brought to the attention of the CBWM organization by a concerned citizen. Consultants were hired to conduct a feasibility study on removing the structure that included hydrological impacts of dam removal, archaeological assessments, legal reviews, and risk assessment for downstream landowners. Public consultation was conducted within local communities and fish surveys confirmed the existence of salmon, American eel, and brook trout within the stream. The decision taken from the feasibility study, public consultation, and fish surveys was that the dam should be removed. Funding for the project was obtained by the CBWM organization. Project planning was finalized through collaboration between the CBWM organization and consultants as well as provincial and federal agencies.

Pre-project monitoring began in 2009 where dissolved oxygen, $\mathrm{pH}$, temperature, conductivity, elevation surveys, benthic macroinvertebrates, grain size analysis, fish passage, and photo monitoring procedures were put in place. It was concluded that the dam was a blockage to fish passage and a safety hazard due to the risk of structural failure. The structure was removed in September 2011, restoring migratory passage to an estimated $19.1 \mathrm{~km}$ section of riverine habitat. Post-project monitoring began immediately after the dam was removed and continued until fall 2012, photo documentation of the project continued until summer 2013.

Post-project monitoring for temperature, conductivity, dissolved oxygen, and $\mathrm{pH}$ did not show any significant changes from pre- to post-removal monitoring conditions; however, there was a slight increase in dissolved oxygen concentrations, and a decrease in water temperature. Although this could be indicative of a beneficial ecosystem shift due to removal of the dam, it is speculated that this was caused by variations in climate from year-to-year. Benthic macroinvertebrate monitoring showed a significant increase in the percent of ephemeroptera, plecoptera, and trichoptera (\%EPT) communities within the former reservoir of the dam indicative of a positive ecosystem shift, whereas the upstream control site showed a slight decrease in \%EPT. Upstream and downstream monitoring locations from the dam removal site showed little change in \%EPT over the course of monitoring. The most notable change between the 2011 to 2012 post-removal timeframe was the percentage of bare soil from $39.8 \%$ to $0.4 \%$ within the restoration area, showing a positive shift in riparian zone reestablishment. Photo documentation shows the reestablishment of plant life and the river's riparian zone during this timeframe. No adverse environmental effects were detected due to the removal of the dam. As part of the post-project monitoring strategy, fish surveys continue to be conducted within 
the river to track the response of fish species to the removal of the dam. At the time of the interview fish surveys were inconclusive and required a longer monitoring period to determine the state of fish stocks.

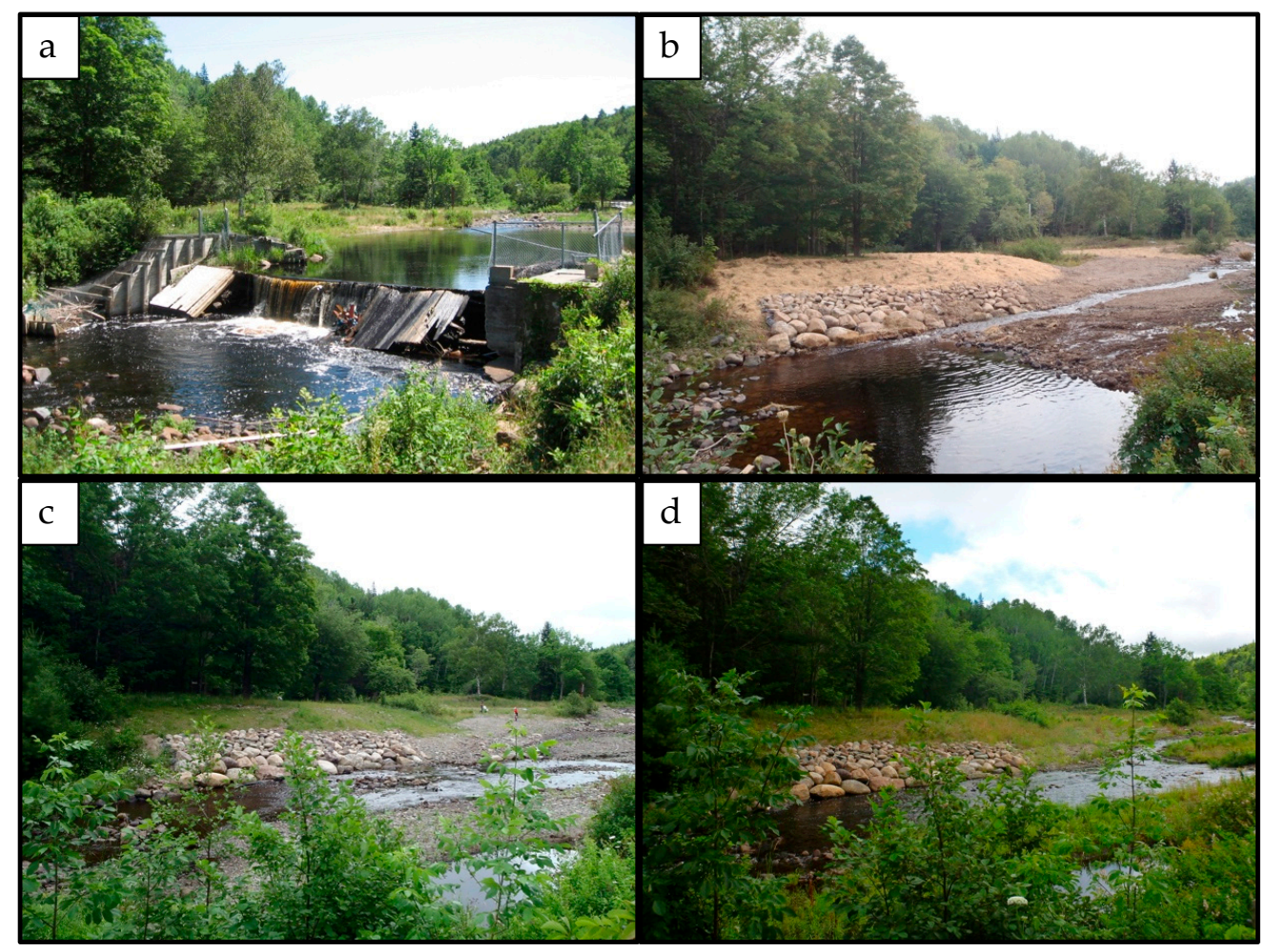

Figure 2. Dam removal project photo documentation. (a) pre-removal 6 August 2009; (b) post-removal 14 September 2011; (c) post-removal 6 July 2012; (d) post-removal 29 July 2013.

On all six projects, participants stated that the desired project outcome was achieved and connectivity was restored to the system. In three of six projects, project success was based on observation and monitoring data of pre- and post-project conditions. In the remaining projects success was based on observation and visual assessment of pre- and post-project conditions.

\subsection{Sediment Control and Riparian Zone Restoration}

The second highest concentration of projects (4), addressed sedimentation control and riparian zone restoration. The goal of these projects was to reduce in-stream sedimentation and to reestablish riparian zones. Monitoring data were used to identify sections of the river where restoration activities would be targeted for three of the projects. Sedimentation sites were also confirmed visually by tracking sediment plumes during rain events, and by assessing stream bank and riparian zone conditions.

"We were monitoring the streams after rain events. We did three samplings on every site; it had to be before a major rain event, during a major rain event, and after a major rain event." (P-06)

"What we were looking at is we were actually tracking the movement of the silt to find out .... So what we were trying to do is actually track it back to see where the source was, to find it." (P-07)

In all cases project funding came from government sources (three federal and one provincial). Funding was for restoration action only, and project specific water monitoring was not conducted. Although water monitoring was conducted throughout the course of the projects at locations upstream 
and downstream from the project locations, the data was inconclusive to changes in water quality indicators. CBWM organizations indicated that changes in water quality are difficult to detect and correlate at the scale that monitoring and restoration was being conducted. They reported that benefits to the ecosystem were observable but not measurable in these cases.

\subsubsection{Case 2-Sediment Control}

Constructed in the early 1960s and operated until the 1980s, a rock quarry was established on a river to mine river rock. The watercourse was altered in order to access the streambed, and when operations ceased, the pit was abandoned. The river remained diverted in such a way that it undermined a large slope adjacent to the river causing significant erosion and sedimentation. The site was approximately $110 \mathrm{~m}$ long and $30 \mathrm{~m}$ high (see Figure 3). In the early 1990s, the CBWM organization and the provincial government conducted a site assessment and concluded that the site should be restored to prevent environmental harm to the river. The environmental concerns identified were sedimentation and the possibility of the river diverting its course for approximately $1 \mathrm{~km}$ through forested land by washing through the bank of the new channel. Restoration work was conducted on the site numerous times by hand, but the site continually washed out under high water conditions. The CBWM organization lacked the capacity and funding to conduct work at a larger scale, but in 1995, the project received federal funding. The CBWM organization hired an engineering firm to develop a restoration plan for this section of the river. The restoration plan received federal approval and provincial permitting was secured. During low-water conditions large rocks were brought into the site and placed against the stream bank with heavy equipment. Gradient controls were constructed within the stream channel so the river could reestablish its natural grade and to create holding pools for migrating fish. The riparian slope was then seeded with grass and trees were planted to stabilize the soil.
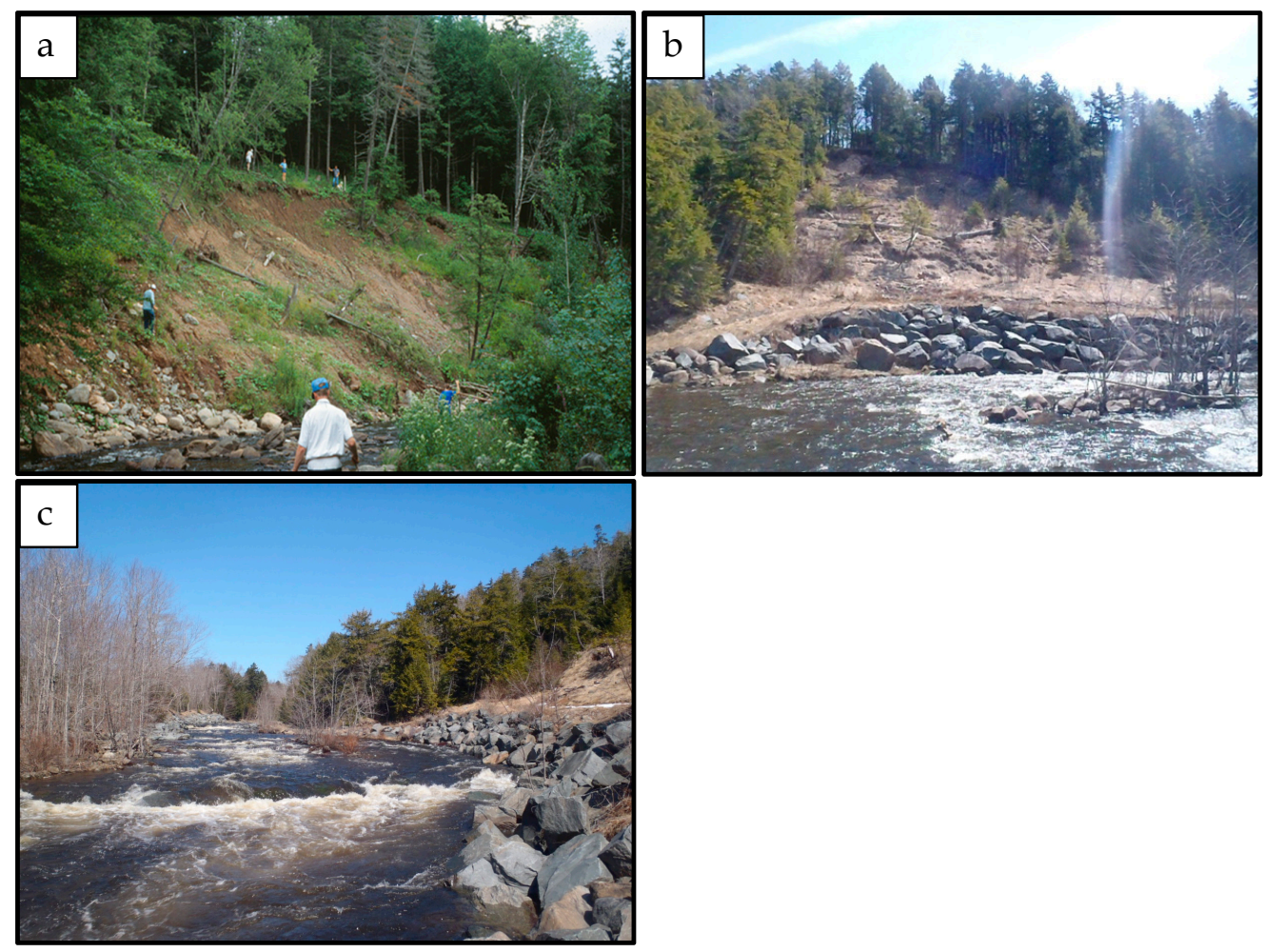

Figure 3. Sediment site rehabilitation: (a) pre-restoration site condition; (b) post-restoration site condition; and (c) post-restoration looking upstream at river channel gradient control structure. 
Throughout the project the site was visually monitored and photographs were taken to document site conditions. As per their protection strategy, the site is still visited periodically to assess conditions and determine whether any maintenance work is required.

"In my opinion we didn't do any proper measurements but [there is a] huge reduction in the amount of silt leaving the site; huge amount, major reduction. And we may have saved the river from re-channelizing itself for about a kilometer or more, which would have meant huge amounts of environmental damage." (P-01)

Figure $3 c$ shows that slope erosion has been mitigated at the site, indicating that sedimentation from the site has been prevented. The slope shows vegetative cover and the footing of the slope no longer descends directly into the river. However, without water monitoring data, it is not possible to determine the amount of sediment that has been prevented or reduced, or any responses in the aquatic environment due to this action.

\subsubsection{Case 3-Riparian Zone Restoration}

As part of a strategy to rehabilitate riparian zones, prevent sedimentation, and control animal access to waterways, one CBWM organization has targeted agricultural landowners seeking permission to implement 'riparian best management practices' on their land. Riparian zone management is of concern throughout this particular watershed as over $50 \%$ of the riparian habitat along the main waterway is on agricultural cropland.

The CBWM organization identified this specific segment of the river through water quality monitoring, which detected a spike in E. coli between two established monitoring locations. Riparian zones within this area were visually assessed to identify areas of concern and potential project locations. The CBWM organization then contacted landowners within the area seeking permission to conduct work on their land. Once approved, a site-specific assessment was conducted and restoration options were identified and discussed with landowners. In this case, a landowner was contacted to discuss an erosion site situated on his/her property. As part of the process, the landowner voluntarily allowed a portion of their land to be established as a riparian buffer where no farm activities would occur. The CBWM organization and landowner agreed on 'live staking' erosion control as a restoration option, a process whereby live cuttings (stakes) from plants are planted in the ground to root and hold soil in place [80]. Permits for conducting the project were obtained from provincial and federal regulating agencies. Stakes were collected from a nearby willow stand and planted by hand on the eroding bank.

“... it went from a big exposed sand bank to a well vegetated bank and now the willow sills that we planted are almost unrecognizable, they're just massive clumps of willow shrub and they're really helping the slope stabilize and other vegetation to establish itself on the soils." (P-08)

Upon completion, the project site was surveyed periodically to monitor the reestablishment of vegetation. Photos of the site and surveys show that vegetation was reestablished and that bank erosion has been controlled (see Figure 4). The impact of this project is observable, although project specific water monitoring was not conducted.

"Observationally, the willow staking definitely retained a lot of soil on the location and allowed establishment of a lot more vegetation at the site; so I mean it's observable, I guess; it's not anything measurable." (P-08)

The lack of water monitoring on this project is attributed to the project funding structure with funding received through the Environment Canada-EcoAction Community Funding Program. Although applicants are required to report on how their project will lead to positive, measurable environmental results, the provided list of environmental indicators for water are not capable of measuring positive responses in water quality or aquatic communities: amount of diverted toxic waste, 
reduction of water consumption, area of shoreline restored, and percentage of recommendations from environmental management plans implemented [81]. The CBWM organization expressed the need for more complete funding sources to help develop future projects.

"It would be nice to have funding in future years, have like three-year continuous funding where we could do more evaluation of the work we are doing. That would help develop projects in the future, but most of it is observational, unfortunately, with this." (P-08)
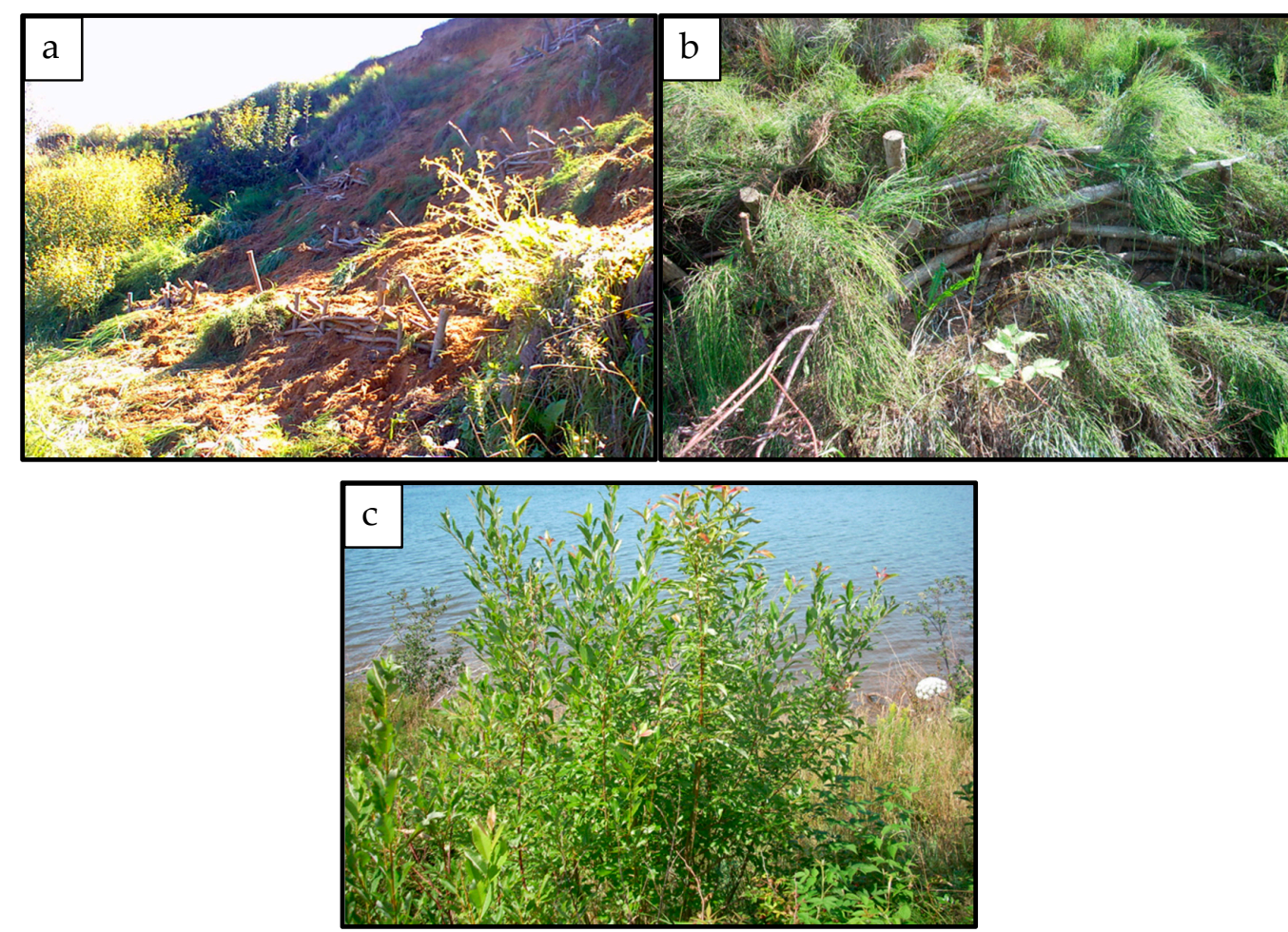

Figure 4. Restoration of an erosion site using live staking. (a) sill boxes installed on an eroding bank for the live staking process; (b) vegetative regrowth on the slope 5 years after restoration; and (c) willow growth from live staking process 5 years after restoration.

\subsection{In-Stream Enhancement}

Two of the 15 projects focused on in-stream enhancement. These projects were digger log installation and in-stream garbage removal. Digger logs were utilized on sections of small streams that were historically channelized in order to reestablish natural flow regimes and create habitat. Site assessment of digger log locations was conducted by the CBWM organization in partnership with a provincial 'Adopt a Stream' program. Sections of river were visually assessed and measured to determine the locations where structures would be installed. Water quality monitoring and measurements of the river's physical characteristics were collected both before and after the installation of a digger log. Fish population surveys were conducted when conditions allowed for electrofishing.

Post-project monitoring indicated that dissolved oxygen content within the water increased directly after installing the digger log, that pool habitat was formed, and that the stream channel was deepened and narrowed. Participants indicated that data on fish populations were inconclusive due to restrictive timeframes on when electrofishing can be conducted and varying results in fish abundance pre- and post-project. Each digger log structure required maintenance on an annual basis, whereby the CBWM organization would remove debris caught by the log, remove rock and sediment from the pool habitat, place rock on the deflector, and replace logs that had been damaged. 
Garbage cleanup from streams does not require project approval as it is considered non-intrusive and has a low probability of negatively affecting streams. This particular CBWM organization has been conducting organized garbage removals for approximately 20 years, relying on the participation of community volunteers. Over this time, the CBWM organization has indicated that the volume of garbage being removed from the river has decreased and that the composition of the garbage has changed.

"Going from 1988 to 2014, we're finding that slowly the garbage content is changing. We're getting less and less car parts, less and less fences, less and less what I call original garbage; people who built a house and threw it [the garbage] in the river. Times are changing." (P-01)

In the first year of conducting the cleanups approximately 50 cars were removed from the river system. Over the years, numerous oil drums, tires, shopping carts, scrap metals, plastics, and rubber waste have been removed from the river system. The garbage that is currently being removed from the river consists primarily of plastics such as grocery bags and bottles. It is uncommon to find newly disposed of construction debris, metals, tires, or oil drums. The result of the garbage removal from the river has been observable, but the CBWM organization stated that they would not know how to monitor the consequent impacts to the river system.

\subsection{Out of Stream Enhancement}

A total of three projects focused on 'out of stream' habitat enhancement'. These included habitat enhancement for monarch butterflies, hedgerow planting in farm fields, and an educational program on river assessment conducted in local schools. These projects relied on community engagement and public support.

Hedgerow planting and monarch habitat enhancement required landowners to voluntarily dedicate sections of land that would no longer be used for agriculture or other uses. The benefit to landowners was that hedgerows would aid in the prevention of topsoil erosion. Monarch habitat utilized the protection of wetland habitat that can aid in protecting streams by establishing riparian buffer zones, and marshes that can capture and help filter nutrient and fertilizer runoff. These wetland areas are normally of low economic value to farmers.

The educational program was administered in schools as a curriculum-matched river assessment program for grades 1-10. Working with teachers, each classroom that participates is assigned a section of a river where the students are responsible for scientific assessment. Facilitated by CBWM staff, students are guided through the process of collecting and analyzing water monitoring parameters and conducting site assessments. The program incorporates both lab and classroom components. At the end of each program students collaboratively decide on an activity to conduct to enhance the stream.

"The whole point of the program was not to have kids collect data for data sake. The kids actually go out, they analyze the stream together and as a group they come up with what they think is the health ratio of the stream and then they come up with an idea of what is affecting it and how to enhance it." (P-07)

These projects demonstrate how CBWM organizations are collaborating with the community to protect their watersheds.

\section{Discussion}

CBWM organizations are actively conducting restoration projects that are intended to mitigate or prevent anthropogenic harm to aquatic ecosystems. An abundance of data exist verifying that anthropogenic stressors such as sedimentation, habitat fragmentation, and riparian zone removal, have negative impacts on water quality, aquatic habitat, biodiversity, and natural stream processes. Excessive sedimentation poses a major threat to aquatic ecosystems [82-84] and "is one of the primary causes of 
stream corridor degradation" [46] (p. 442). When fragmentation restricts movement within aquatic ecosystems preventing species from accessing critical habitat, it has harmful effects on biodiversity that can lead to population decline or even extinction [85-89]. The removal of riparian zones leaves streams more susceptible to terrestrial influences, and can negatively impact in stream habitat and water quality $[47,52,53,57]$. The literature on the response within aquatic ecosystems to the mitigation or removal of such anthropogenic stressors in many cases is unclear.

Through interviews that focused on restoration projects, major themes that correspond to criteria for successful restoration within academic literature were identified. Findings showed that: (1) projects are planned and implemented with the identification of clear project goals and objectives; (2) projects included baseline monitoring, but the collection of project specific water-monitoring data was rare; (3) post-project reporting was completed for all projects that required regulatory approval, reports were made publicly available for seven of the projects; (4) a majority of restoration projects were targeted at reconnecting habitat and restoring processes that create or maintain habitat. Each of these findings is discussed in detail in the following sections.

\subsection{Project Goals and Objectives}

All of the restoration projects were planned and implemented with clear goals and objectives of the desired end result of each project. These were normally simple and straightforward involving the removal or mitigation of anthropogenic influences that are known to degrade aquatic ecosystems, and thus present challenges for source water protection. A majority of projects involved governmental resource management agencies, and required regulatory approval. CBWM organizations were primarily responsible for the project planning process and determining the intended project outcome, but they also partnered with experts, academics, other CBWM organizations, and government agencies to aid with project planning to fill knowledge gaps within the organizations.

\subsection{Collection of Baseline Data}

The long-standing establishment of the CBWM organizations that participated in our study shows a commitment and invested interest to the long term within their watersheds. This establishment has allowed for the long-term collection of baseline data and documentation of pre-restoration conditions within their watersheds. Although CBWM organizations were monitoring at a watershed scale, it was expressed by participants that water monitoring at this scale was not sensitive enough to detect environmental changes directly correlated to the restoration work being conducted. The collection of project specific water monitoring data was rare, and factors such as cost, capacity, and the project funding structure often inhibited the collection of such data. The literature states that larger-scale restoration projects provide the best opportunity to track changes within aquatic ecosystems $[46,47]$. This proved true for the restoration activities assessed during this study for biological indicators such as benthic macroinvertebrates, and most physical and chemical water monitoring parameters. Changes in physical characteristics were evident throughout all projects, showing that physical change can be documented at a small-scale.

Photographs were able to document the physical characteristics of pre-restoration site conditions. This form of baseline documentation was collected for all projects. When paired with physical measurements collected by CBWM organizations of pre-restoration conditions, this documentation allowed for a comparison of pre- and post-restoration where physical change was both observable and measurable. Changes such as the removal of barriers, establishment of riparian zones, and securing of erosion sites were evident within photographs. This can be used to track physical changes in restoration site conditions from before and after restoration is conducted.

\subsection{Project Reporting}

Project reporting is a critical step in the progression of restoration practices and techniques in that it can allow for knowledge mobilization around aspects of restoration that are and are not 
successful $[11,33,34,51]$. Reporting can provide practitioners of restoration projects with valuable information on how to design and implement future projects. Two types of reporting were identified during this research: regulatory reporting and reports made available to the public.

Projects that received regulatory approval required the submission of a project completion report. This report is supplied to the regulatory agency but there is generally no requirement to make the report publicly available. The reporting is utilized for compliance and informing the regulatory agency but cannot be utilized by other practitioners. The regulatory reporting criteria vary depending on the type and scale of project; some forms of reporting are extensive while others are minimal. For approximately half of the restoration projects examined during our research, reports were also made publicly available by the CBWM organization, showing transparency in reporting on project outcomes as recommended in the literature $[11,33,34,51]$. These reports were posted online on the CBWM organizations' websites.

\subsection{Prioritizing Restoration Activities}

Based on the classification of restoration projects discussed, the majority focused on the reconnection of habitat within aquatic ecosystems. The remaining projects contributed both to the preservation and protection of watersheds, and restoring processes that maintain and create habitat. The prioritization of restoration activities was largely driven by the perceived benefit of project type along with factors such as cost, access to project location, project funding, and group capacity. Working with limited financial, staff, and land capacity, CBWM organizations showed a tendency to target restoration projects that are documented to yield the highest potential to benefit aquatic ecosystems, while requiring minimal cost and capacity. Funding streams often dictated the types of restoration that were conducted on an annual basis. The prioritization of project locations was influenced by access to the site. This limitation was most evident in watersheds with a high percentage of privately owned land, as landowner permission is required to gain access to project locations and conduct any terrestrially-based work. In these cases the prioritization of restoration was defaulted to where landowner permission was granted, meaning that projects were not always conducted at the optimal locations.

\section{Conclusions}

Our findings broadly link to our overarching research purpose about the value of restoration activities conducted by CBWM organizations in terms of observable or measurable benefits within aquatic ecosystems for overall source water protection. However, what our findings further reveal is that in trying to achieve these benefits, there are a number of challenges that CBWM organizations are facing. Our research demonstrates that although restoration projects were successful in the mitigation or removal of targeted impacts, projects often lacked the corresponding water monitoring data required to track post-project changes within the aquatic environment. Only a portion of the projects had corresponding water monitoring data of chemical, physical, and biological traits that showed improvements from pre-restoration to post-restoration conditions. Funding, in many cases, restricted the extent to which project monitoring could be conducted and also influenced project scope and size [11]. This often led to projects that lacked the capacity to conduct large-scale restoration and rigorous scientific monitoring. Consequently, CBWM organizations highlighted the difficulty of detecting the effects of small-scale projects, particularly at a watershed scale.

Where funding was available to conduct in-depth monitoring, CBWM organizations showed the capability to implement rigorous source water protection and monitoring programs that tested a wide range of environmental parameters. Where standardized methods of assessment were available, such as for culvert assessments, CBWM organizations showed the willingness and ability to adopt and utilize these methods. Rigor decreased in projects with limited funding or funding that was specifically allocated for project action only. These projects often targeted known anthropogenic impacts that have been documented to have a high potential to degrade aquatic ecosystems. In these cases the 
impact was visual (e.g., erosion, riparian zone degradation, channelization, fragmentation), and the result of restoration action was evident. For these instances it can be shown that restoration action had mitigated the anthropogenic impact, but there is little evidence that supports the effectiveness of post-project protection, or that the aquatic ecosystem responded positively to these actions.

Our study appears to be the first of its kind in the peer-reviewed literature that utilized photographic documentation to discuss the process of conducting restoration projects with CBWM organizations. All of the projects had clear and observable outcomes that were visible through photographic documentation, and further confirmed through visual monitoring and assessment. Overall, our findings present important insights into how restoration projects are planned and implemented with clear goals and objectives utilizing academic, professional, and regulatory expertise. Although documentation of how these processes transfer to restoration projects where observable ecosystem benefits are evident, the restoration process remains challenged. The lack of funding, capacity, and monitoring procedures make the existence of complementary water monitoring data, which would be representative of ecosystem benefits, a rarity.

Acknowledgments: The authors gratefully acknowledge the financial support of the Water Economics, Policy and Governance Network and the Social Sciences and Humanities Research Council of Canada. Special thanks are extended to the community-based water monitoring organizations and participants who dedicated their time to be involved in this research. Additional thanks are given to the research assistants, particularly Robert Stefanelli, who helped to format the paper according to the journal's requirements.

Author Contributions: Chris Garda, Heather Castleden and Cathy Conrad conceived and designed the study; Chris Garda performed the data collection; Chris Garda and Heather Castleden analyzed the data; Chris Garda led the writing of this paper with Heather Castleden providing intellectual guidance and revisions to earlier drafts.

Conflicts of Interest: The authors declare no conflict of interest.

\section{References}

1. Richter, B.D.; Braun, D.P.; Mendelson, M.A.; Master, L.L. Threats to imperiled freshwater fauna. Conserv. Biol. 1997, 11, 1081-1093. [CrossRef]

2. Malmqvist, B.; Rundle, S. Threats to the running water ecosystems of the world. Environ. Conserv. 2002, 29, 134-153. [CrossRef]

3. Dudgeon, D.; Arthington, A.H.; Gessner, M.O.; Kawabata, Z.I.; Knowler, D.J.; Lévêque, C.; Naiman, R.J.; Prieur-Richard, A.H.; Soto, D.; Stiassny, M.L.; et al. Freshwater biodiversity: Importance, threats, status and conservation challenges. Biol. Rev. 2006, 81, 163-182. [CrossRef] [PubMed]

4. Chapman, J.M.; Proulx, C.L.; Veilleux, M.A.; Levert, C.; Bliss, S.; André, M.E.; Lapointe, N.W.; Cooke, S.J. Clear as mud: A meta-analysis on the effects of sedimentation on freshwater fish and the effectiveness of sediment-control measures. Water Res. 2014, 56, 190-202. [CrossRef] [PubMed]

5. Karr, J.R.; Toth, L.A.; Dudley, D.R. Fish communities of Midwestern rivers: A history of degradation. Bioscience 1985, 35, 90-95. [CrossRef]

6. Harper, D.; Ebrahimnezhad, M.; Climent, I.C.F. Artificial riffles in river rehabilitation: Setting the goals and measuring the successes. Aquat. Conserv. Mar. Freshw. Ecosyst. 1998, 8, 5-16. [CrossRef]

7. Bond, N.; Lake, P. Local habitat restoration in streams: Constraints on the effectiveness of restoration for stream biota. Ecol. Manag. Restor. 2003, 4, 193-198. [CrossRef]

8. Litvan, M.E.; Stewart, T.W.; Pierce, C.L.; Larson, C.J. Effects of grade control structures on the macroinvertebrate assemblage of an agriculturally impacted stream. River Res. Appl. 2008, 24, $218-233$. [CrossRef]

9. Miller, S.; Budy, P.; Schmidt, J. Quantifying macroinvertebrate responses to in-stream habitat restoration: Applications of meta-analysis to river restoration. Restor. Ecol. 2010, 18, 8-19. [CrossRef]

10. Dudgeon, D. Threats to freshwater biodiversity in a changing world. In Global Environmental Change; Freedman, B., Ed.; Springer: Dordrecht, The Netherlands; Heidelberg, Germany; New York, NY, USA, 2014; pp. 243-253.

11. Pander, J.; Geist, J. Ecological indicators for stream restoration success. Ecol. Indic. 2013, 30, 106. [CrossRef]

12. Bliss, J.; Aplet, G.; Hartzell, C.; Harwood, P.; Jahnige, P.; Kittredge, D.; Lewandowski, S.; Soscia, M.L. Community-based ecosystem monitoring. J. Sustain. For. 2001, 12, 143-167. [CrossRef] 
13. Vaughan, H.; Whitelaw, G.; Craig, B.; Stewart, C. Linking ecological science to decision-making: Delivering environmental monitoring information as societal feedback. Environ. Monit. Assess. 2003, 88, 399-408. [CrossRef] [PubMed]

14. Pollock, R.; Whitelaw, G. Community-based monitoring in support of local sustainability. Local Environ. 2005, 10, 211-228. [CrossRef]

15. Sharpe, A.; Conrad, C. Community based ecological monitoring in Nova Scotia: Challenges and opportunities. Environ. Monit. Assess. 2006, 113, 395-409. [CrossRef] [PubMed]

16. Kebo, S.; Bunch, M. Canadian ENGOs in governance of water resources: Information needs and monitoring practices. Environ. Monit. Assess. 2013, 185, 9451-9460. [CrossRef] [PubMed]

17. Conrad, C.; Daoust, T. Community-based monitoring frameworks: Increasing the effectiveness of environmental stewardship. Environ. Manag. 2008, 41, 358-366. [CrossRef] [PubMed]

18. Whitelaw, G.; Vaughan, H.; Craig, B.; Atkinson, D. Establishing the Canadian community monitoring network. Environ. Monit. Assess. 2003, 88, 409-418. [CrossRef] [PubMed]

19. Tulloch, A.; Possingham, H.; Joseph, L.; Szabo, J.; Martin, T. Realising the full potential of citizen science monitoring programs. Biol. Conserv. 2013, 165, 128-138. [CrossRef]

20. Johnson, M.F.; Hannah, C.; Acton, L.; Popovici, R.; Karanth, K.K.; Weinthal, E. Network environmentalism: Citizen scientists as agents for environmental advocacy. Glob. Environ. Chang. 2014, 29, 235. [CrossRef]

21. Carr, A.J.L. Why do we all need community science? Soc. Natl. Resour. 2004, 17, 841-849. [CrossRef]

22. Darwall, W.R.T.; Dulvy, N.K. An evaluation of the suitability of non-specialist volunteer researchers for coral reef fish surveys. Mafia Island, Tanzania-A case study. Biol. Conserv. 1996, 78, 223-231. [CrossRef]

23. Monk, J.; Ierodiaconou, D.; Bellgrove, A.; Laurenson, L. Using community-based monitoring with GIS to create habitat maps for a marine protected area in Australia. Mar. Biol. Assoc. UK 2008, 88, 865-871. [CrossRef]

24. Fore, L.; Paulsen, K.; O'Laughlin, K. Assessing the performance of volunteers in monitoring streams. Freshw. Biol. 2001, 46, 109-123. [CrossRef]

25. Engel, S.R.; Voshell, J.J.R. Research-volunteer biological monitoring: Can it accurately assess the ecological condition of streams? Am. Entomol. 2002, 48, 164. [CrossRef]

26. Nicholson, E.; Ryan, J.; Hodgkin, D. Community data-where does the value lie? Assessing confidence limits of community collected water quality data. Water Sci. Technol. 2002, 45, 193-200. [PubMed]

27. Foster-Smith, J.; Evans, S.M. The value of marine ecological data collected by volunteers. Biol. Conserv. 2003, 113, 199-213. [CrossRef]

28. Conrad, C.; Hilchey, C. A review of citizen science and community-based environmental monitoring: Issues and opportunities. Environ. Monit. Assess. 2011, 176, 273-291. [CrossRef] [PubMed]

29. Khalil, B.; Ouarda, T.B.M.J.; St-Hilaire, A.; Chebana, F. A statistical approach for the rationalization of water quality indicators in surface water quality monitoring networks. J. Hydrol. 2010, 386, 173-185. [CrossRef]

30. Osborne, L.; Bayley, P.; Higler, L.; Statzner, B.; Triska, F.; Iversen, T. Restoration of lowland streams: An introduction. Freshw. Biol. 1993, 29, 187-194. [CrossRef]

31. Hobbs, R.; Norton, D. Towards a conceptual framework for restoration ecology. Restor. Ecol. 1996, 4, 93-110. [CrossRef]

32. Ehrenfeld, J. Defining the limits of restoration: The need for realistic goals. Restor. Ecol. 2000, 8, 2-9. [CrossRef]

33. Lake, P. On the maturing of restoration: Linking ecological research and restoration. Ecol. Manag. Restor. 2001, 2, 110-115. [CrossRef]

34. Palmer, M.A.; Bernhardt, E.S.; Allan, J.D.; Lake, P.S.; Alexander, G.; Brooks, S.; Carr, J.; Clayton, S.; Dahm, C.N.; Shah, J.F.; et al. Standards for ecologically successful river restoration. J. Appl. Ecol. 2005, 42, 208-217. [CrossRef]

35. Feld, C.K.; Birk, S.; Bradley, D.C.; Hering, D.; Kail, J.; Marzin, A.; Melcher, A.; Nemitz, D.; Pedersen, M.L.; Pletterbauer, F.; et al. From natural to degraded rivers and back again: A test of restoration ecology theory and practice. Adv. Ecol. Res. 2011, 44, 119-209.

36. Alexander, G.G.; Allan, J.D. Ecological success in stream restoration: Case studies from the Midwestern United States. Environ. Manag. 2007, 40, 245-255. [CrossRef] [PubMed]

37. Chapman, M.G.; Underwood, A.J. The need for a practical scientific protocol to measure successful restoration. Wetlands 2000, 19, 28-48. 
38. Keenleyside, K.A.; Dudley, N.; Cairns, S.; Hall, C.M.; Stolton, S. Ecological Restoration for Protected Areas: Principles, Guidelines and Best Practices; IUCN: Gland, Switzerland, 2012.

39. Parks Canada. Canadian Parks and Protected Areas: Helping Canada Weather Climate Change. Available online: http:/ / www.parks-parcs.ca/english/CPC\%20Climate\%20Change\%20Report\%20FINAL\%20engLR. pdf (accessed on 28 November 2016).

40. Kondolf, G. Five elements for effective evaluation of stream restoration. Restor. Ecol. 1995, 3, $133-136$. [CrossRef]

41. Graf, W.L. Damage control: Restoring the physical integrity of America's rivers. Ann. Assoc. Am. Geogr. 2001, 91, 1-27. [CrossRef]

42. Pess, G.R.; Beechie, T.J.; Williams, J.E.; Whitall, D.R.; Lange, J.L.; Klochak, J.R. Watershed assessment techniques and the success of aquatic restoration activities. In Strategies for Restoring River Ecosystems: Sources of Variability and Uncertainty in Natural and Managed Systems; Wissmar, R., Bisson, P., Eds.; American Fisheries Society: Bethesda, MD, USA, 2003; pp. 185-201.

43. Wohl, E.; Angermeier, P.; Bledsoe, B.; Kondolf, G.; MacDonnell, L.; Merritt, D.; Palmer, M.A.; Poff, N.L.; Tarboton, D. River restoration. Water Resour. Res. 2005, 41, 1-12. [CrossRef]

44. Hilderbrand, R.H.; Watts, A.C.; Randle, A.M. The myths of restoration ecology. Ecol. Soc. 2005, 10, 19. [CrossRef]

45. Roni, P.; Beechie, T.; Bilby, R.; Leonetti, F.; Pollock, M.; Pess, G. A review of stream restoration techniques and a hierarchical strategy for prioritizing restoration in Pacific Northwest watersheds. N. Am. J. Fish. Manag. 2002, 22, 1-20. [CrossRef]

46. Shields, F.D.; Cooper, C.M.; Knight, S.S.; Moore, M.T. Stream corridor restoration research: A long and winding road. Ecol. Eng. 2003, 20, 441-454. [CrossRef]

47. Lake, P.; Bond, N.; Reich, P. Linking ecological theory with stream restoration. Freshw. Biol. 2007, 52, 597-615. [CrossRef]

48. Jungwirth, M.; Muhar, S.; Schmutz, S. The effects of recreated instream and ecotone structures on the fish fauna of an epipotamal river. Hydrobiologia 1995, 303, 195-206. [CrossRef]

49. Kondolf, G.; Micheli, M. Evaluating stream restoration projects. Environ. Manag. 1995, 19, 1-15. [CrossRef]

50. Schiemer, F.; Baumgartner, C.; Tockner, K. Restoration of floodplain rivers: The 'Danube restoration project'. Regul. Rivers Res. Manag. 1999, 15, 231-244. [CrossRef]

51. Nienhuis, P.; Bakker, J.; Grootjans, A.; Gulati, R.; De Jonge, V. The state of the art of aquatic and semi-aquatic ecological restoration projects in the Netherlands. Hydrobiologia 2002, 478, 219-233. [CrossRef]

52. Geist, J. Seven steps towards improving freshwater conservation. Aquat. Conserv. Mar. Freshw. Ecosyst. 2015, 25, 447-453. [CrossRef]

53. Kauffman, J.B.; Beschta, R.L.; Otting, N.; Lytjen, D. An ecological perspective of riparian and stream restoration in the western United States. Fisheries 1997, 22, 12-24. [CrossRef]

54. Jähnig, S.; Brabec, K.; Buffagni, A.; Erba, S.; Lorenz, A.; Ofenböck, T.; Verdonschot, F.M.; Hering, D. A comparative analysis of restoration measures and their effects on hydromorphology and benthic invertebrates in 26 central and southern European rivers. J. Appl. Ecol. 2010, 47, 671-680. [CrossRef]

55. Ruwanza, S.; Gaertner, M.; Esler, K.J.; Richardson, D.M. The effectiveness of active and passive restoration on recovery of indigenous vegetation in riparian zones in Western Cape, South Africa: A preliminary assessment. S. Afr. J. Bot. 2013, 88, 132-141. [CrossRef]

56. Beechie, T.; Pess, G.; Roni, P.; Giannico, G. Setting river restoration priorities: A review of approaches and a general protocol for identifying and prioritizing actions. N. Am. J. Fish. Manag. 2008, 28, 891-905. [CrossRef]

57. Geist, J.; Hawkins, S. Habitat recovery and restoration in aquatic ecosystems: Current progress and future challenges. Aquat. Conserv. Mar. Freshw. Ecosyst. 2016, 26, 942-962. [CrossRef]

58. Bohn, B.A.; Kershner, J.L. Establishing aquatic restoration priorities using a watershed approach. J. Environ. Manag. 2002, 64, 355-363. [CrossRef]

59. Dahm, C.; Cummins, K.; Valett, H.; Coleman, R. An Ecosystem view of the restoration of the Kissimmee River. Restor. Ecol. 1995, 3, 225-238. [CrossRef]

60. Bernhardt, E.; Palmer, M. River restoration: The fuzzy logic of repairing reaches to reverse catchment scale degradation. Ecol. Appl. 2011, 21, 1926-1931. [CrossRef] [PubMed]

61. Patton, M.Q. Qualitative Research and Evaluation Methods; Sage Publications: Thousand Oaks, CA, USA, 2002. 
62. McKenna, S.A.; Iwasaki, P.G.; Main, D.S. Key informants and community members in community-based participatory research: One is not like the other. Prog. Community Health Partnersh. Res. Educ. Act. 2011, 5, 387-397.

63. Mueller, M.; Geist, J. Conceptual guidelines for the implementation of the ecosystem approach in biodiversity monitoring. Ecosphere 2016, 7, 1-19. [CrossRef]

64. Mueller, M.; Pander, J.; Geist, J. Taxonomic sufficiency in freshwater ecosystems: Effects of taxonomic resolution, functional traits, and data transformation. Freshw. Sci. 2013, 32, 762-778. [CrossRef]

65. Leach, W.; Pelkey, N.; Sabatier, P. Stakeholder partnerships as collaborative policymaking: Evaluation criteria applied to watershed management in California and Washington. J. Policy Anal. Manag. 2002, 21, 645-670. [CrossRef]

66. Whiting, L.S. Semi-structured interviews: Guidance for novice researchers. Nurs. Stand. 2008, 22, 35-40. [CrossRef] [PubMed]

67. Stewart, C.J.; Cash, W.B. Interviewing: Principles and Practices; McGraw-Hill: New York, NY, USA, 2011.

68. Gibson, W.J.; Brown, A. Working with Qualitative Data; SAGE Publications Ltd.: London, UK, 2009.

69. Willig, C. Introducing Qualitative Research in Psychology; McGraw-Hill Education: Maidenhead, UK, 2013.

70. Crabtree, B.; Miller, W.L. Doing Qualitative Research, 2nd ed.; Sage Publications: Thousand Oaks, CA, USA, 1999.

71. Tracy, S. Qualitative Research Methods Collecting Evidence, Crafting Analysis, Communicating Impact; Wiley-Blackwell: Chichester, UK, 2013.

72. Harper, D. Talking about pictures: A case for photo elicitation. Vis. Stud. 2002, 17, 13-26. [CrossRef]

73. Aronson, J. A pragmatic view of thematic analysis. Qual. Rep. 1994, 2, 1-3.

74. Parker, M.A. Fish Passage-Culvert Inspection Procedures. Available online: http://www.env.gov.bc.ca/ cariboo/env_stewardship/wrp/manuals/culv2000.pdf (accessed on 8 March 2017).

75. Coté, D.; Kehler, D.G.; Bourne, C.; Wiersma, Y.F. A new measure of longitudinal connectivity for stream networks. Landsc. Ecol. 2009, 24, 101-113. [CrossRef]

76. Clarkin, K.; Connor, A.; Furniss, M.J.; Gubernick, B.; Love, M.; Moynan, K.; Wilson-Musser, S. National Inventory and Assessment Procedure-for Identifying Barriers to Aquatic Organism Passage at Road-Stream Crossings. Available online: https://www.fs.fed.us/biology/nsaec/fishxing/publications/PDFs/NIAP.pdf (accessed on 8 March 2017).

77. Department of Fisheries and Oceans (DFO). Practitioners Guide to Fish Passage for DFO Habitat Management Staff, Version 1.1. Available online: http://www.dfo-mpo.gc.ca/Library/343445.pdf (accessed on 28 November 2016).

78. Environment Canada. Performance indicators. Available online: http://www.ec.gc.ca/ecoaction/default. asp?lang=En\&n=93C81A93-1 (accessed on 28 November 2016).

79. Canadian Council of Ministers of the Environment (CCME). Canadian Environmental Quality Guidelines; Canadian Council of Ministers of the Environment: Winnipeg, MB, Canada, 2002.

80. Fay, L.; Akin, M.; Shi, X. Cost-Effective and Sustainable Road Slope Stabilization and Erosion Control; Transportation Research Board: Washington, DC, USA, 2012.

81. United States Environmental Protection Agency (USEPA). National Water Quality Inventory: 2000 Report. Report No. EPA-841-R-02-001. Available online: https://www.epa.gov/sites/production/ files/2015-09/documents/2000_national_water_quality_inventory_report_to_congress.pdf (accessed on 28 November 2016).

82. Benoy, G.A.; Sutherland, A.B.; Culp, J.M.; Brua, R.B. Physical and ecological thresholds for deposited sediments in streams in agricultural landscapes. J. Environ. Qual. 2002, 41, 31-40. [CrossRef] [PubMed]

83. Fausch, K.; Torgersen, C.; Baxter, C.; Li, H. Landscapes to riverscapes: Bridging the gap between research and conservation of stream fishes. BioScience 2002, 52, 483-498. [CrossRef]

84. Fahrig, L. Effects of habitat fragmentation on biodiversity. Ann. Rev. Ecol. Evolut. Syst. 2003, 34, 487-515. [CrossRef]

85. Letcher, B.; Nislow, K.; Coombs, J.; O’Donnell, M.; Dubreuil, T.; Svensson, E. Population response to habitat fragmentation in a stream-dwelling brook trout population (habitat fragmentation effects). PLOS ONE 2007, 2, E1139. [CrossRef] [PubMed] 
86. Gardner, C.; Coghlan, S.; Zydlewski, J.; Saunders, R. Distribution and abundance of stream fishes in relation to barriers: Implication for monitoring stream recovery after barrier removal. River Res. Appl. 2013, 29, 65-78. [CrossRef]

87. Branco, P.; Segurado, P.; Santos, J.; Ferreira, M. Prioritizing barrier removal to improve functional connectivity of rivers. J. Appl. Ecol. 2014, 51, 1197-1206. [CrossRef]

88. Osborne, L.; Kovacic, D. Riparian vegetated buffer strips in water quality restoration and stream management. Freshw. Biol. 1993, 29, 243-258. [CrossRef]

89. Floyd, T.; MacInnis, C.; Taylor, B. Effects of artificial woody structures on Atlantic salmon habitat and populations in a Nova Scotia stream. River Res. Appl. 2009, 25, 272-282. [CrossRef]

(C) 2017 by the authors. Licensee MDPI, Basel, Switzerland. This article is an open access article distributed under the terms and conditions of the Creative Commons Attribution (CC BY) license (http:/ / creativecommons.org/licenses/by/4.0/). 